\title{
CASE REPORT Klippel-Feil Syndrome: A Rare Case Report
}

\author{
Sally DE Mohammed ${ }^{1}$, Mona AM Ali², Hassan Osman ${ }^{3}$
}

\begin{abstract}
Background: Klippel-Feil syndrome (KFS) is defined as a congenital fusion of two or more cervical vertebrae. The most common signs are short neck, low hairline at the back of the head, and restricted mobility of neck.

Case description: A term, female child weighing 2,522 g was born to a 34-year-old, a third gravida mother with a previous history of two cesarean sections. She was delivered by an elective cesarean section and had Apgar scores of 4 and 6 at 1 and 5 minutes, respectively. Ultrasound done at 22-week gestational age showed a single, viable fetus with hydrocephalous, short broad neck, and extended limbs. After adequate obstetric, genetic counseling and given all the information about the risks involving this pregnancy, the parents opted for conservative management without any intervention. On examination, she had the typical triad of KFS, including very short neck, low occipital hairline, and reduced bilateral neck movements. The child died immediately due to respiratory distress. Her parents refused to consent for postmortem scanning.

Conclusion: Although KFS is a rare syndrome encountered less commonly and a classical triad is present in almost $50 \%$ cases, one should closely investigate for other anomalies associated with it for better, early management and rehabilitation.
\end{abstract}

Keywords: Cervical fusion, Klippel-Feil syndrome, Ultrasound.

Donald School Journal of Ultrasound in Obstetrics and Gynecology (2020): 10.5005/jp-journals-10009-1624

\section{INTRODUCTION}

Klippel-Feil syndrome (KFS) was first described by Maurice Klippel and Andre Feil in 1912 in a patient with congenital fusion of cervical vertebrae. ${ }^{1}$ Klippel-Feil syndrome is a complex syndrome of osseous and visceral anomalies that include the classical clinical triad of short neck, limitation of head and neck movements, and low posterior hairline. ${ }^{2}$ This malformation is responsible for the limitation of movement of the head and a significant risk of spinal cord injury. ${ }^{3}$ The exact incidence and prevalence are unknown because of unavailability of population screening studies. The estimated incidence is 1 in 40,000-42,000 births, ${ }^{4,5}$ and the predominance of women (3:2) has been reported. Klippel-Feil syndrome can be asymptomatic. However, skeletal, urogenital, cardiac, neurological, hindbrain, ocular, craniofacial, otolaryngeal, limb, and digital anomalies have all been associated with KFS in varying degrees. ${ }^{6}$ This variable expression together with KFS heterogeneity has greatly complicated the understanding and diagnosis of this developmental syndrome. ${ }^{6,7}$ The authors report a case of KFS which was managed conservatively.

\section{Case Description}

A 34 years old woman, GIII PII both were by C/S presented at lan Donald ultrasound department for first-time scan at 22-week gestational age. There was consanguineous marriage, and an antenatal period was uneventful. There was no history of any drug intake or significant infection during the antenatal period. Ultrasound showed a single, viable fetus with hydrocephalous, short broad neck, and extended limbs (Fig. 1). After adequate obstetric, genetic counseling and given all the information about the risks involving this pregnancy, the parents opted for conservative management without any intervention. On a growth scan at 33 weeks, the cervical vertebrae were found to be fused with evidence of polyhydramnios (Figs 2 and 3). The patient underwent elective cesarean section at 37 weeks due to repeated cesarean section; she gave birth to female baby weighing 2,522 $\mathrm{g}$ and had Apgar scores
${ }^{1}$ Department of Obstetrics and Gynecology, Nahda College, Khartoum, Sudan

${ }^{2}$ Research Department, Faculty of Medicine, University of Medical Sciences and Technology, Khartoum, Sudan

${ }^{3}$ Graduate College, lan Donald Master of Advanced Obstetric Ultrasound, University of Medical Sciences and Technology, Khartoum, Sudan

Corresponding Author: Sally DE Mohammed, Department of Obstetrics and Gynecology, Nahda College, Khartoum, Sudan, Phone: +249 912690390, e-mail: d.sally222@gmail.com

How to cite this article: Mohammed SDE, Ali MAM, Osman H. KlippelFeil Syndrome: A Rare Case Report. Donald School J Ultrasound Obstet Gynecol 2020;14(1):14-16.

Source of support: Nil

Conflict of interest: None

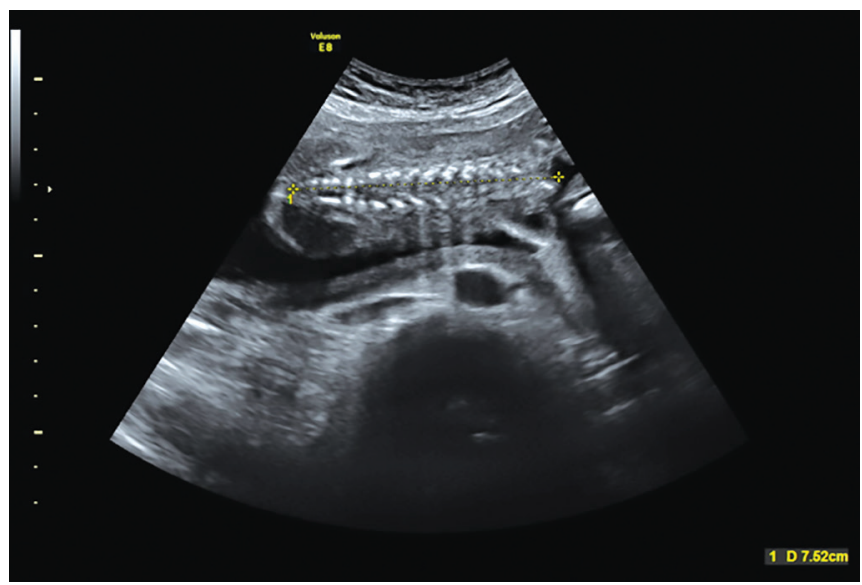

Fig. 1: Ultrasound image showing short spine and fusion of the cervical part

(0) The Author(s). 2020 Open Access This article is distributed under the terms of the Creative Commons Attribution 4.0 International License (https://creativecommons. org/licenses/by-nc/4.0/), which permits unrestricted use, distribution, and non-commercial reproduction in any medium, provided you give appropriate credit to the original author(s) and the source, provide a link to the Creative Commons license, and indicate if changes were made. The Creative Commons Public Domain Dedication waiver (http://creativecommons.org/publicdomain/zero/1.0/) applies to the data made available in this article, unless otherwise stated. 


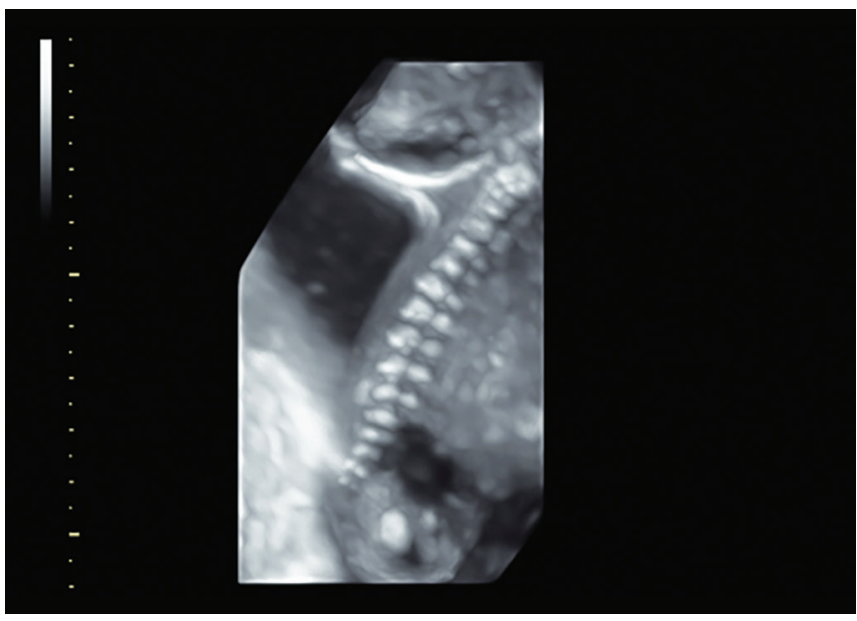

Fig. 2: 3D scan showing the vertebral column with fused cervical vertebrae

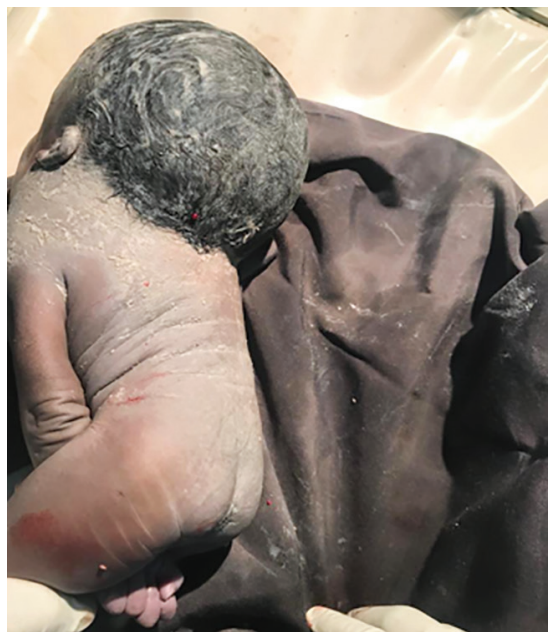

Fig. 4: Postnatal image showing low hair-line, webbed neck and the back of the newborn

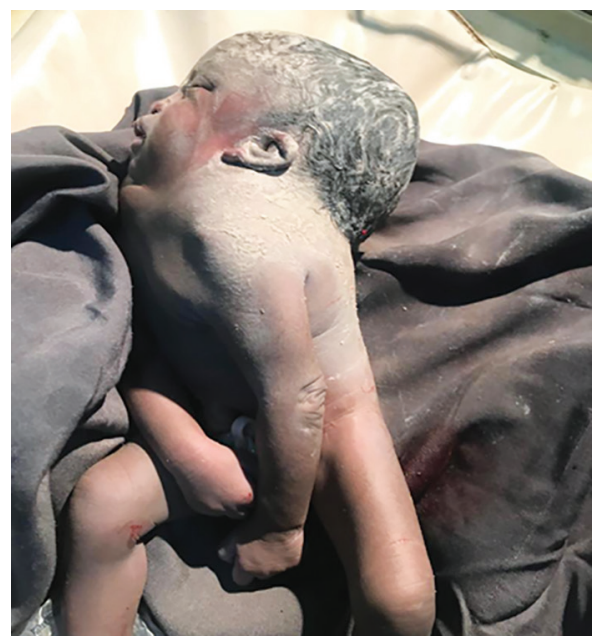

Fig. 6: Lateral view of the newborn with Klippel-Feil syndrome

of 4 and 6 at 1 and 5 minutes, respectively (Fig. 4). On examination, she was found to have short webbed neck, low hair line, short body length (Fig. 5). There was no obvious organomegaly. She had the typical triad of KFS, including very short neck, low occipital hairline, and reduced bilateral neck movements. The child died

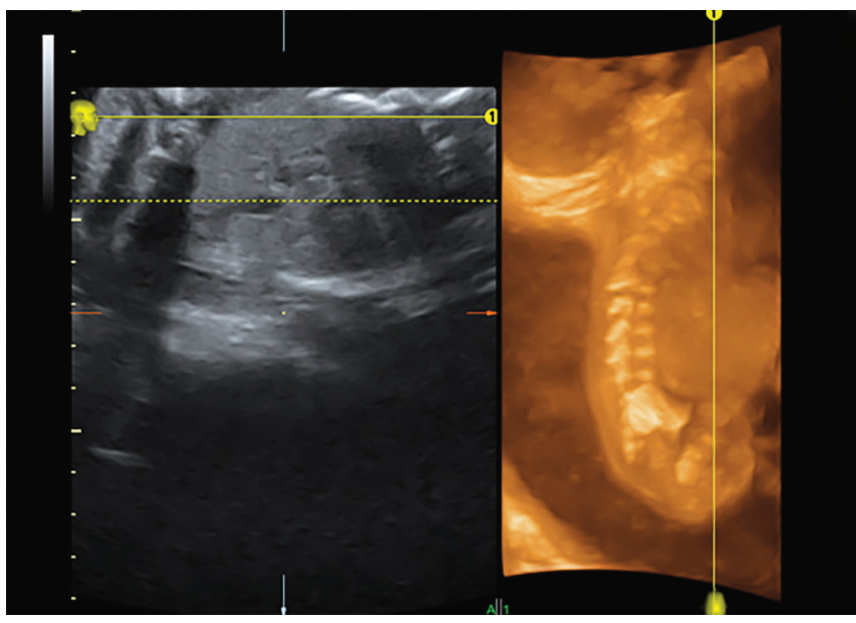

Fig. 3: Volume contrast image - showing fused cervical spine

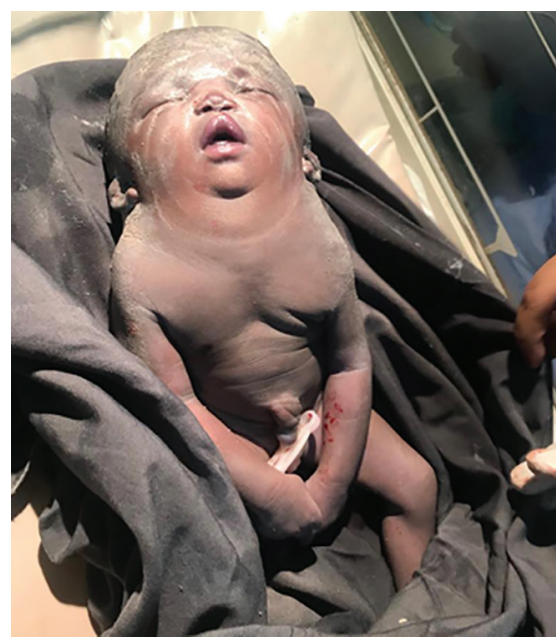

Fig. 5: Postnatal image showing hyperextended neck

immediately due to respiratory distress. The child's parents denied any postmortem scanning (Fig. 6).

\section{Discussion}

Klippel-Feil syndrome was originally described in 1912 by Maurice Klippel and Andre Feil. ${ }^{8}$ Their seminal report of this condition was based on a 46-year-old male French tailor who was found to have a short neck, low posterior hairline, and limited cervical movement. Such findings have since become synonymous with the term "clinical triad." However, many authors had described KFS existing without this triad. When we reviewed history, we found that this anomaly had been described as early as the 16th century, where union between the second and third cervical vertebrae was found in an Egyptian mummy of about 500 BC. ${ }^{8,9}$ Klippel-Feil syndrome is a complex, congenital condition with heterogeneity in both phenotypic expressions and etiological background. It has many associated deformities like Sprengel's deformity, synkinesia, scoliosis, facial asymmetry, hearing impairment, ocular abnormalities, cleft palate, congenital heart diseases, lung defects, and genitourinary problems such as abnormal kidneys or reproductive organs. ${ }^{10,11}$ The exact cause of KFS has yet to be determined, although some have suggested a genetic aetiology, ${ }^{12}$ while others attribute environmental factors such as alcohol 
consumption as a cause. ${ }^{11}$ Recent molecular studies have suggested that mutations of the MEOX1 gene may cause a recessive subtype of the syndrome. ${ }^{9}$ Mutations in the GDF6 gene, expressed in vertebrae and within the intervertebral disc, GDF3 genes, and PAX1 have all been implicated in the pathogenesis of the disease. ${ }^{10,11}$ More recently, a homozygous frame shift mutation in a protein-coding gene (RIPPLY2) has been found to be responsible for a new type of autosomal recessive KFS. ${ }^{13}$ The identification of mutations in these genes may lead to new advancement of treatment and possible explanation of associated anomalies.

High-index of suspicion should be maintained when diagnosing KFS, irrespective of clinical triad findings, especially in patients who exhibit associated spinal findings such as congenital scoliosis or spina bifida.

As such, early diagnosis of KFS is necessary in identifying high-risk cases and design measures to prevent potentially fatal outcomes.

\section{CONCLUSION}

Although KFS is rare syndrome encountered less commonly and a classical triad is present in almost $50 \%$ cases, one should closely investigate for other anomalies associated with it for better, early management and rehabilitation.

\section{Consent}

Verbal explanation was given to the parents and an informed written consent was obtained both for the writing up and taking the pictures. A written informed consent was obtained from the parents for publication of this case report. The authors assure that the consent form will be produced at any time upon request.

\section{Author Contributions}

Sally Damra: Primary doctor who diagnosed the syndrome and followed the patient, she also edited and proof read the final version. Mona Awadalla: Conceptualized the manuscript, proof read and edited the final version. Hassan Osman: Consultant obstetrician and ultrasound expert who confirmed the diagnosis.

\section{Acknowledgments}

Authors acknowledge the cooperation of lan Donald ultrasound department and Academy Charity Teaching Hospital residents who participated in appointing the patient and following up. They also appreciate the commitment and compliance of the patient who reported the required data and attended for the regular follow-up.

\section{References}

1. Jones KL. Smith's recognizable pattern of human kolkotta. malformation, 5th ed., Philadelphia: WB Saunders Company; 1997.

2. Pledger SR, Cervical Spine Disease. Ortho Secrets, 1989. 3rd ed., vol. 55; 2003. pp. 107-118.

3. James W, Berger T, Elston D. Andrews' Diseases of the Skin: Clinical Dermatology, 10th ed., Saunders; 2005. ISBN 0-7216-2921-0.

4. Isidor B, David A. Two girls with short stature, short neck, vertebral anomalies, sprengel deformity and intellectual disability. Eur J Med Genet 2015;58(1):47-50. DOI: 10.1016/j.ejmg.2014.11.001.

5. Clarke RA, Catalan G, Diwan AD, et al. Heterogeneity in Klippel-Feil syndrome: a new classification. Pediatr Radiol 1998;28(12):967-974. DOI: 10.1007/s002470050511.

6. Clarke RA, Kearsley JH, Walsh DA. Patterned expression in familial Klippel-Feil syndrome. Teratology 1996;53(3):152-157. DOI: 10.1002/ (SICI)1096-9926(199603)53:3<152::AID-TERA2>3.0.CO;2-6.

7. Nguyen VD, Tyrrel R. Klippel-Feil syndrome: patterns of bony fusion and wasp-waist sign. Skeletal Radiol 1993;22(7):519-523. DOI: 10.1007/BF00209100.

8. Gorlin RJ, Cohen M, Hennekam R. Syndromes of the head and neck, 4th ed., Oxford University Press; 2001. p. 1142.

9. Mohamed JY, Faqeih E, Alsiddiky A, et al. Mutations in MEOX1, encoding mesenchyme homeobox 1, cause Klippel-Feil anomaly. Am J Hum Genet 2013;92(1):157-161. DOI: 10.1016/j.ajhg.2012. 11.016 .

10. Pizzutillo PD. Klippel-Feil syndrome. In: The cervical spine. Philadelphia: The Cervical Spine Research Society, Lippincott; 1983. pp. 174-188.

11. David KM, Thorogood PV, Stevens JM, et al. The dysmorphic cervical spine in Klippel-Feil syndrome: interpretations from developmental biology. Neurosurg Focus 1999;6(6):e1. DOI: 10.3171/foc.1999. 6.6.4.

12. Gunderson $\mathrm{CH}$, Greenspan RH, Glaser GH, et al. The Klippel-Feil syndrome: genetic and clinical reevaluation of cervical fusion. Medicine (Baltimore) 1967;46(6):491-512. DOI: 10.1097/00005792$196711000-00003$.

13. Karaca E, Yuregir OO, Bozdogan ST, et al. Rare variants in the notch signaling pathway describe a novel type of autosomal recessive Klippel-Feil syndrome. Am J Med Genet A 2015;167A(11):2795-2799. DOI: 10.1002/ajmg.a.37263. 